December 2008

IMF Country Report No. 08/372

\title{
Canada: Report on the Observance of Standards and Codes- FATF Recommendations for Anti-Money Laundering and Combating the Financing of Terrorism
}

This Report on the Observance of Standards and Codes on the FATF Recommendations for Anti-Money Laundering and Combating the Financing of Terrorism for Canada was prepared by the Financial Action Task Force on Money Laundering (FATF), using the assessment methodology adopted by the FATF in February 2004 and endorsed by the Executive Board of the IMF in March 2004. The views expressed in this document, as well as in the full assessment report, are those of the FATF and do not necessarily reflect the views of the Government of Canada or the Executive Board of the IMF.

A copy of the full assessment report can be found on the website of the FATF at http://www.FATFGAFI.ORG. 



\section{FATF+GAFI \\ Financial Action Task Force Groupe d'action financière}

\section{CANADA}

Report on Observance of Standards and Codes FATF Recommendations for Anti-Money Laundering and Combating the Financing of Terrorism 
(C) 2008 FATF/OECD

All rights reserved. No reproduction or translation of this publication may be made without prior written permission.

Applications for such permission should be made to:

FATF Secretariat, 2 rue André-Pascal, 75775 Paris Cedex 16, France Fax: +33144306137 or Contact@fatf-gafi.org 


\title{
Report on Observance of Standards and Codes
}

\section{FATF Recommendations for Anti-Money Laundering and Combating the Financing of Terrorism}

\author{
CANADA
}

\section{Introduction}

1. This Report on the Observance of Standards and Codes for the FATF 40 Recommendations for AntiMoney Laundering and 9 Special Recommendations Combating the Financing of Terrorism was prepared by the Financial Action Task Force (FATF). The report provides a summary ${ }^{1}$ of the AML/CFT measures in place in Canada as of June 2007, the level of compliance with the FATF 40+9 Recommendations, and contains recommendations on how the AML/CFT system could be strengthened. The views expressed in this document have been agreed by the FATF, but do not necessarily reflect the views of the Boards of the IMF or World Bank.

\section{Key findings}

2. Canada has strengthened its overall AML/CFT regime since its last FATF mutual evaluation (1997) by implementing a number of changes both in terms of statutory amendments and structural changes. The most important developments were the enactment of the Proceeds of Crime (Money Laundering) and Terrorist Financing Act and the creation of the Canadian Financial Intelligence Unit (FINTRAC) in 2000. With regard to the legal measures (ML and TF offences, confiscation, freezing mechanisms), the legal framework is generally in line with the FATF standards however further steps could be taken to enhance effective implementation. The Canadian FIU has been provided with extensive powers and responsibilities. Since it became operationally effective in November 2001, FINTRAC has undertaken extensive outreach and assistance to reporting entities and has developed close relationships with government partners. There are concerns about its effectiveness in disclosing money laundering and terrorist financing cases to law enforcement authorities.

3. Canada has recently introduced a significant set of new requirements for financial institutions that aim at implementing the FATF standards. A large number of these new requirements will only be in force in June 2008, and these, together with further amendments applicable to DNFBPs due to come into force in December 2008, have not been analysed in the context of this evaluation. As it currently stands however, the preventive system is generally insufficient to meet the FATF Recommendations. In addition, certain financial institutions that undertake financial activities, as defined by the FATF Recommendations, are not currently covered by the AML/CFT regime. Moreover, both the scope of coverage and the AML/CFT requirements for the designated non-financial businesses and professions (DNFBPs) are insufficient to meet the FATF standards. Although FINTRAC and the Office of the Superintendent of Financial Institutions (OSFI) are involved in comprehensive supervisory actions, there are varying degrees of supervision for AML/CFT purposes in the financial sector.

4. Illicit proceeds from a variety of criminal activities contribute to the ongoing money laundering situation in Canada with drug trafficking as the source of much of the money laundered. Other sources of proceeds of crime include, but are not limited to, prostitution rings, contraband smuggling, illegal arms sales, migrant smuggling, and white-collar crime such as securities offences, real estate fraud, credit card

\footnotetext{
${ }^{1}$ A copy of the full Mutual Evaluation Report can be found on the FATF website: www.fatf-gafi.org.
} 
fraud and telemarketing fraud. While there is no estimate for the total annual proceeds of crime, drug sales are estimated to amount to several billion dollars.

5. The money laundering methods used in Canada have remained relatively consistent in recent years. They essentially consist of: smuggling; money service businesses and currency exchanges; casinos; purchase of real estate; wire transfers; establishment of offshore corporations; credit cards, stored value cards and new payment methods; use of nominees; use of foreign bank accounts; use of professional services (lawyers, accountants, etc.); and reinvestment and distribution in illicit drugs. At the placement stage, criminals are using money service businesses or casinos. Electronic funds transfers are being used for layering and at the integration stage, criminal proceeds are used to purchase high-value assets in attempts to conceal the origin of the funds. Most recently, there have been signs that criminals are turning to such methods as Internet payments or cross-border movement of gold bullion.

6. Canadian law enforcement authorities have identified a number of terrorist organisations operating in Canada. Investigations have shown that terrorist cells have a tendency to remain self-sufficient by generating funds locally. In some instances, they may do so by committing petty crimes, such as welfare fraud or credit card fraud. In other instances, cell members have started businesses to glean financial information from unsuspecting customers in order to clone credit cards and commit identity thefts. Law enforcement authorities have intelligence indicating that suspected terrorist entities in Canada are raising funds through drug trafficking.

7. The financial sector in Canada is diverse, mature, well developed and includes many service providers. The sector is significantly integrated, as many players offer similar services and a small group of "financial groups" or conglomerates offer a large variety of financial products directly or through subsidiaries. A wide range of financial institutions exist in Canada and are subject to AML/CFT requirements: banks; credit unions and caisses populaires; life insurance companies; trust companies (that offer services similar to those provided by banks but can also administer estates, personal and institutional trusts, trustee pension plans and agency contracts); securities firms and money service businesses (MSBs). Financial leasing, factoring, finance companies (i.e. entities specialised in consumer lending, credit cards, equipment financing and small business loans that are not loan companies), providers of e-money, Internet payment providers and cheque cashers are also engaged in financial activities as defined by the FATF.

8. The following DNFBPs are currently subject to AML/CFT requirements: casinos, real estate agents and accountants. In addition, the Government of Canada has recently enacted regulations to cover the following DNFBPs as of December 2008: lawyers, notaries (relevant in Québec and British Columbia only) and dealers in precious metals and stones. Trust and company service providers are not separately recognised nor regulated as a discrete category of entity in Canada and do not fall under the AML/CFT regime. Trust companies, accountants, lawyers and other independent legal professions provide most services of this nature, though it appears that some other businesses exist that engage in TCSP activity.

\section{Legal System and Related Institutional Measures}

9. The anti-money laundering offences are comprehensive and Canada generally meets the requirements under Recommendations 1 and 2. The money laundering offence (section 462.31 Criminal Code (CC)) is part of a broader proceeds of crime regime designed to cover all obligations in the 1988 Vienna Convention and the 2000 Palermo Convention. Section 462.31 encompasses acts of using, transferring the possession of, sending or delivering to any person or place, transporting, transmitting, altering, disposing of or otherwise dealings with, in any manner and by any means, any property or any proceeds of any property. The Section 462.31 offence is however technically inconsistent with the relevant UN Conventions in that it has a specific intent mental element that is not consistent with those Conventions. Designated offence refers to virtually all indictable offences and also covers all ancillary offences. 
10. There is also a second offence of possession of proceeds of crime (s.354(1), CC), whereby it is an offence to knowingly possess money or property derived directly or indirectly from any indictable Canadian criminal offence or any foreign offence, that had it been committed in Canada would have been an indictable offence in Canada. The two offences cover almost all of the requirements of R.1 \& 2, with only some minor technical deficiencies (see comments above). Despite this, the emphasis on and preference for pursuing the predicate crimes and the offence of possession of property obtained by crime, and the low number of s.462.31 convictions indicates that the statutes available for countering ML are not being used as effectively as they could be. Canada should develop a more proactive approach to prosecuting the specific money laundering charge under s.462.31.

11. Canada has three criminal offences related to the financing of terrorism (s. 83.02-83.04, CC). The offences are broadly defined and wide-reaching in effect. These offences cover the provision or collection of property intending or knowing that it will be used, in whole or in part, to carry out or facilitate a "terrorist activity", to possess or use property for that purpose, or to benefit a terrorist group. The offences and related provisions cover all types of property; include ancillary offences; and generally meet all the requirements of the FATF standards. The offences have been in existence for several years and there have been a large number of investigations, but only three persons have been charged with terrorist financing and these charges have not been heard yet. There have been no convictions. Given these facts, the authorities should consider how the TF offence could be more effectively implemented. The overall effectiveness of the TF offence and regime is an issue that the authorities will need to pay close attention to going forward.

12. The CC and the Controlled Drugs and Substances Act (CDSA) contain extensive provisions that authorise the forfeiture of proceeds of crime and instrumentalities used in or intended for use in offences. Forfeiture is available for all money laundering and terrorist financing offences, as well as all predicate offences. Conviction for any indictable offence or a conspiracy or attempt to commit an indictable offence is a prerequisite to forfeiture. There are also discretionary provisions for a fine in lieu of forfeiture, which is the action that Canada has taken to seek to deprive criminals of property of equivalent value. If there are no assets to which such a fine can be applied the court must impose a jail sentence, otherwise the fine is enforced as a civil judgement against any other property of the offender, but cannot be applied against third party property in such cases.

13. Other legislative provisions are broad and allow the authorities to restrain or seize and search for proceeds of crime or instrumentalities. The definition of "property" is broad, and includes any benefit or advantage obtained or "derived directly or indirectly" as a result of the offence. The available data on seizure/restraint and forfeiture is not comprehensive and suggests that it could be more effective.

14. Canada's United Nations Act and its related regulations enable the Canadian government to implement the decisions contained in the resolutions of the United Nations Security Council. The United Nations Al-Qaida and Taliban Regulations (UNAQTR), and the Regulations Implementing the United Nations Resolutions on the Suppression of Terrorism (RIUNRST), were enacted under the authority of Canada's United Nations Act. These regulations allow Canada to list a terrorist individual or entity for the purpose of freezing the funds or assets owned or controlled by that individual or entity or its associates. A third listing mechanism exists under the Criminal Code for threats to Canada's domestic security. Canada has laws and regulations to freeze terrorist funds or other assets of persons designated in the context of S/RES/1267(1999) and S/RES/1373(2001) that are in line with the legal international requirements. However, although the lists are published in the Canada Gazette, there needs to be more communication on listed persons provided to certain categories of financial institutions and other potential asset holders as well as more clear and practical guidance to reporting entities (including DNFBPs and MSBs) that may be holding targeted funds or other assets concerning their obligations in taking action under freezing 
mechanisms. Canada should also enhance the existing measures to monitor the compliance with the legislation governing the obligations under SRIII (except for federally regulated financial institutions supervised by OSFI).

15. In 2000, Canada established the Financial Transactions and Reports Analysis Centre of Canada (FINTRAC) as a national centre for receiving, analyzing and disseminating information concerning suspected money laundering or terrorist financing. In addition to mandatory reporting by financial institutions and DNFBPs, FINTRAC can receive voluntary information concerning suspicions of money laundering or terrorist financing from the general public and various other sources, including information about cases being investigated by law enforcement agencies and foreign FIUs. FINTRAC has a high level of operational independence and information held by FINTRAC is securely protected.

16. Under the PCMLTFA, FINTRAC is authorized to disseminate financial information to domestic authorities for further action when it has reasonable grounds to suspect that the information would be relevant and useful to the investigation or prosecution of a money laundering or terrorist activity offence. FINTRAC provides comprehensive guidance to reporting entities regarding the manner of reporting and the procedures that should be followed when reporting. In February 2006, FINTRAC launched an updated secure online report capture system that provides reporting entities with a reliable mechanism to file reports through the Internet. However, the format of reporting forms is perceived by certain reporting entities as being too rigid and reduces the capacity to communicate a maximum level of information. FINTRAC develops very few typologies and is not allowed by the PCMLTFA to ask (directly or indirectly) for additional financial information from reporting entities in line with the FATF requirements.

17. The information that FINTRAC can provide to a disclosure recipient is referred to as "designated information" and includes key details that identify individuals or entities and their financial transactions. Under the PCMLTFA, FINTRAC has the authority to collect information from databases maintained for law enforcement or national security purposes and in respect of which an agreement is entered into. FINTRAC currently has access to two major national police databases. However, FINTRAC has limited access to intelligence information from certain administrative authorities (such as the Canada Revenue Agency (CRA)).

18. There are serious issues in relation to effectiveness with respect to FINTRAC. Although Canada decided to establish a FIU that would make maximum use of advanced technologies in its analytical work, the number of staff dedicated to the analysis of potential ML/FT cases is low, especially in light of the number of reports FINTRAC receives, and FINTRAC has decided to concentrate its efforts on large or significant ML/TF cases. At the time of the on-site visit, the feedback provided by some organizations that receive FINTRAC disclosures was generally negative (unsatisfactory timelines for disclosures, relatively limited added value of FINTRAC disclosures in law enforcement investigations, FINTRAC disclosures positively contributed to existing investigations but rarely generated new ones). It seems that since March 2007, more positive feedback has been received from law enforcement authorities, especially with regard to the timeliness of disclosures. Another important issue is that, FINTRAC disclosures are largely based on voluntary information reports made by law enforcement authorities ( $80 \%$ of cases). This raises serious concerns with respect to the capability of FINTRAC to generate new ML/TF cases independent from existing investigations. Finally, until 2007, no conviction for ML or TF had directly resulted from a FINTRAC disclosure.

19. While all Canadian police forces can investigate money laundering and terrorist financing offences, the Royal Canadian Mounted Police (RCMP), and in particular its Integrated Proceeds of Crime Initiative, IPOC, Units, and, to a lesser extent, the provincial law enforcement authorities in Ontario (the Ontario Provincial Police) and Québec (Sûreté du Québec) undertake virtually all money laundering and terrorist financing investigations. The powers and capacity of the law enforcement services are sound and they have 
appropriate investigative techniques at their disposal. The RCMP acknowledges that, due to resources constraints, it essentially focuses its resources on large, complex ML investigations related to organised crime groups. The RCMP could undertake a larger number of investigations and tackle a larger spectrum of ML/TF cases with additional resources. In addition, consideration should be given to improving the educational and training programmes provided for judges and courts concerning ML and TF offences.

20. Canada has implemented comprehensive measures to detect the physical cross-border transportation of currency and bearer negotiable instruments that are related to ML or FT. These measures are fully in line with the FATF requirements and are effectively implemented.

\section{Preventive Measures - Financial Institutions}

21. To combat money laundering, the Canadian Parliament enacted the Proceeds of Crime (Money Laundering) Act which received Royal Assent on 29 June 2000. To help fight terrorism, it amended and renamed the legislation the Proceeds of Crime (Money Laundering) and Terrorist Financing Act (PCMLTFA). The PCMLTF Regulations and the PCMLTF Suspicious Transaction Reporting Regulations implement the provisions of the Act. In October 2006, a Bill proposing to further strengthen the PCMLTFA was introduced in Parliament to expand the scope of preventive measures. The Bill received Royal Assent in December 2006. Some new provisions of the PCMLTFA came into force on 10 February 2007 and on 27 June 2007, the Regulations Amending Certain Regulations Made Under the PCMLTFA were enacted and published in the Canada Gazette. Some of these provisions came into force on 30 June 2007; others will take effect on 23 June 2008. A second package of regulatory amendments, the Proceeds of Crime (Money Laundering) and Terrorist Financing Registration Regulations setting out a framework for the registration of MSBs will come into force on 30 June 2008. Further regulations were enacted on 26 December 2007 that will come into force in December 2008. However, for the purpose of this report, none of the changes coming into force after June 2007 were considered.

22. FINTRAC (for all reporting parties), OSFI (for Federally Regulated Financial Institutions) and IDA (for securities dealers) have developed guidelines to assist persons and entities subject to the PCMLTFA and the Regulations to understand their obligations. IDA By-laws, Policies and Regulations are legally enforceable and can be considered as "other enforceable means". OSFI and FINTRAC Guidance are considered as non-binding guidance for the purpose of this report.

23. In Canada, certain entities that undertake financial activities, as defined by the FATF Recommendations, are not currently covered by the AML/CFT regime (except for entities that are caught because they also engage in financial activities which are captured under the regime). These include: financial leasing entities; factoring entities; finance companies (i.e. mostly entities specialized in consumer lending, issuing certain types of credit cards, equipment financing and unregulated small business lending entities); providers of e-money; Internet payment providers $^{2}$; and cheque cashers ${ }^{3}$ when their only activity is cashing cheques issued to denominated persons. Canada considers that these entities pose little or no threat of money laundering/terrorist financing. Canada's approach to risk is not in line with the FATF approach as defined in the Methodology where a list of activities and operations must be covered by the AML/CFT regime unless there is a proven low risk of ML/TF. Canada has applied the opposite approach and has extended coverage of the PCMLTFA only to activities for which there is a proven ML/TF risk. Moreover, the risk assessment process carried out by Canada to reach conclusions on the exposure of certain sectors to ML/TF risks is either non-existent or very fragmented and ad-hoc.

\footnotetext{
${ }^{2}$ Internet payment and e-money providers are only subject to the Act if they also offer funds remittance or transmission services and, as such, would be considered money services businesses.

${ }^{3}$ Cheque cashing businesses that also offer money remittance services are included in the definition of MSBs under the PCMLTFA and are therefore subject to the requirements of the PCMLTFA.
} 
24. Customer identification measures in Canada are currently insufficient to meet the FATF standards ${ }^{4}$. Current legislation does not impose a requirement for financial institutions to conduct CDD in all cases covered by the FATF standards, including when there is a suspicion of ML or TF or when financial institutions have doubts about the veracity or adequacy of previously obtained CDD data. The current customer identification measures for natural persons are insufficient and, except for IDA supervised entities, financial institutions are not required to understand the ownership and control structure of the customer nor obliged to determine the natural persons that ultimately own or control the customer. There are currently no requirements (except for IDA supervised entities) to obtain information on the purpose and intended nature of the business relationship. There is no obligation to perform enhanced due diligence for higher risk categories of customer, business relationship or transaction and the current approach is not in line with the FATF standards regarding situations of lower risk. Finally, the timing of verification of customer identity is inadequate for certain financial entities vis-à-vis certain customers. Financial institutions (except IDA supervised entities in some circumstances) are not prohibited from opening an account or commencing a business relationship or performing a transaction and they are not required to make a suspicious transaction report where they are unable to identify the customer.

25. At the time of the on-site visit, there were no specific legislative or other enforceable requirements in relation to PEPs and limited requirements in relation to correspondent banking relationships. Provisions in relation to the prevention of misuse of technological developments in ML/TF schemes and the mitigation of risks associated with non-face to face business were not in compliance with the FATF requirements. New provisions entered into force in June 2007 for correspondent banking, and will enter into force in June 2008 in relation to PEPs. Although introduced business arrangements exist in Canada, Canada has not implemented adequate requirements in relation to third party introduced business.

26. There is no financial institution secrecy law that inhibits the implementation of AML/CFT requirements. Canada's record-keeping requirements are generally satisfactory. At the time of the on-site visit, Canada had not implemented SRVII on wire transfers.

27. Under the PCMLTFA, there is currently no explicit provision requiring financial institutions to pay special attention to all complex, unusual large transactions. Such a requirement may only be indirectly deduced from (a) the requirement to report to FINTRAC suspicious transactions that may be related to money laundering or terrorist financing, and (b) the obligation to report large international electronic funds transfers and large cash transactions. Canada should ensure that the new provisions coming into force in June 2008 will fully and effectively address these issues. The obligation to give special attention to business relationships and transactions with persons from countries which do not or insufficiently apply the FATF Recommendations is also not fully met.

28. All financial institutions subject to the PCMLTFA are required to report to FINTRAC transactions of any amount for which there are reasonable grounds to suspect are related to the commission of a money laundering offence or a terrorist financing offence. However, certain categories of financial institution (see comments above) are not subject to the PCMLTFA and, consequently, to any mandatory reporting requirement to FINTRAC. Under the current legislation, reporting entities are only required to report completed transactions to FINTRAC. As from June 2008, the reporting requirement will be broadened to the reporting of any suspicious attempted transactions related to money laundering or terrorist financing. The total number of STRs sent by the financial sector appears satisfactory (an average of 20,000 every year since 2004). The different financial institutions however contributed unequally to the total number of STRs

\footnotetext{
${ }^{4}$ New provisions will enter into force in June 2008 and December 2008. These provisions will impose a number of additional requirements including in the following areas: CDD, politically exposed persons, SR VII, record keeping, reporting of suspicious transactions, requirements for DNFBPs, and beneficial ownership information in company legislation. These changes were not assessed as the changes fall outside the period of the evaluation.
} 
(securities dealers, life insurance companies and life insurance brokers and dealers have sent limited numbers of STRs).

29. No criminal or civil proceedings lie against persons and entities for making a suspicious transaction report, a terrorist property report, a large cash transaction report or an electronic funds transfer report in good faith or for providing FINTRAC with information about suspicions of money laundering or of the financing of terrorist activities. The provisions in relation to tipping off are also fully in line with the FATF standards. FINTRAC gives very detailed guidance related to STRs to assist financial institutions in implementing and complying with STR requirements and provides satisfactory general feedback to large financial institutions. Specific feedback is provided within the legislative limitations. The PCMLTFA requires reporting entities to submit reports to FINTRAC on large cash transactions and electronic funds transfers and the FATF requirements in that area are met.

30. The requirements in relation to internal procedures, policies and controls to prevent ML and FT are generally sound, but some changes are needed to bring them fully in line with the FATF standards. FRFIs have generally adopted enterprise-wide AML/CFT standards based on the OSFI Guideline and supervisory practice. There is no specific requirement regarding the enforcement of AML/CFT measures consistent with Canadian or FATF requirements in foreign branches and subsidiaries.

31. In addition, Canadian financial entities are prohibited from entering into a business relationship with shell banks or with foreign financial institutions that have correspondent banking relationships with shell banks. Canada is broadly in compliance with the FATF requirements in this regard.

32. FINTRAC is responsible for ensuring compliance with the PCMLTFA. FINTRAC's compliance program is based on a collaborative risk-based approach divided into two categories: the promotion of compliance and the monitoring of compliance. FINTRAC has signed MOUs with certain financial and gaming regulators or supervisors to share AML/CFT supervisory information. In addition, some regulators have provisions under their own legislation or codes of conduct that impose similar requirements to, or which complement the key provisions in the PCMLTFA. Globally, there are unequal degrees of regulation and supervision, depending on the sectors and provinces although OSFI is responsible for regulating well over $80 \%$ of the Canadian financial sector as measured by total assets. It is worth mentioning that the entities which are currently not subject to the PCMLTFA are not subject to prudential supervision either.

33. The number of examinations performed by FINTRAC appears to be relatively low compared with the total number of reporting financial entities (potentially more than 100, 000) although a single FINTRAC examination can cover a large number of reporting entities (e.g., in the case of life insurance companies/agents and securities firms/dealers). Even including examinations conducted by FINTRAC's MOU partners, the figures remain rather low, except for the banking and federally regulated trust companies sectors which have a good supervisory coverage by OSFI. The use of a sophisticated risk-based model helps FINTRAC prioritise its supervisory activities. Those activities encompass not only examinations of reporting entities but also guidance, outreach, self-assessment tools and follow-up actions after examinations.

34. The securities sector is regulated by provincial securities regulatory authorities (SRAs) and has been subject to limited AML/CFT supervision. The on-site AML/CFT assessments conducted by OSFI since 2003 in the federally regulated life insurance sector amount to $90 \%$ of the industry measured by its assets but less than $10 \%$ of the supervised population. AML/CFT supervision by provincial financial supervisors appears to be less effective for life insurance agents because AML/CFT controls are mostly assessed by FINTRAC. In addition, despite the focus put on that sector, FINTRAC had managed to perform controls on only 60 credit unions and caisses populaires up to mid-2007, out of a total population of 1,250 reporting entities. 
35. Under the current version of the PCMLTFA and its Regulations, FINTRAC has limited powers of enforcement against reporting entities and their directors or senior management for failure to comply with or properly implement AML/CFT requirements. Currently, FINTRAC cannot impose penalties and is limited to referring cases to law enforcement for investigation. Strengthening the sanctions regime in June 2008 with the introduction of administrative and monetary penalties should be a crucial enhancement of the system. The current PCMLTFA provides for a series of criminal sanctions for contraventions of various provisions of the Act. These can lead to criminal penalties of up to $\$ 2$ million in fines and five years in prison for non-compliance. The December 2006 amendments expanded the regime of criminal sanctions to the violations of most of the provisions of the PCMLTFA and regulations.

36. OSFI has a wider range of possible enforcement actions or sanctions than FINTRAC. Nevertheless, sanctions remain infrequently used, and do not appear to be sufficiently effective, proportionate and dissuasive, though this may be partially due to the early intervention strategy adopted by OSFI. In the securities sector, except for IDA which has effectively applied in a number of cases heavy sanctions to its members for non compliance with AML/CFT standards, it seems that the powers of sanction have generally not been used by SRAs or SROs in that area, as they have rarely issued specific rules or regulations related to AML/CFT and consider such issues to be mainly FINTRAC's responsibility.

37. Measures aimed at preventing criminals or their associates from holding a significant or controlling interest or holding a management function in a financial institution, as well as the "fit and proper" principle are widespread. There is no systematic harmonization of these requirements across the federal and provincial systems. At the time of the on-site visit, there was no compulsory obligation for FRFIs to implement screening procedures for directors or senior management, after the initial incorporation or authorisation procedures are concluded.

38. There was no registration regime for MSBs at the time of the on-site visit although Canada has created a federal registration regime that will enter into force in June 2008. The preventive measures currently applicable to MSBs (especially in relation to CDD, reporting of suspicious transactions or SRVII) present serious weaknesses and the MSB sector is subject to a limited range of preventive measures that are not in compliance with international standards. In addition, the sanction regime applicable to MSBs that fail to comply with the PCMLTFA is currently not effective, proportionate and dissuasive. Canada should ensure effective implementation of the registration system for MSBs in force in June 2008 and ensure that the requirements applicable to MSBs fully meet the FATF requirements.

\section{Preventive Measures - Designated Non-Financial Businesses and Professions (DNFBPs)}

39. The PCMLTFA currently covers casinos, real estate brokers and sales representatives and accountants and accounting firms. Lawyers, Quebec Notaries, BC Notaries, dealers in precious metals and stones, Internet casinos, and TCSPs are not currently captured by the PCMLTFA and therefore are not subject to the requirements under Recommendations 5, 6 and 8-11. It should be noted that Internet casinos are illegal in Canada, but servers hosting such activity exists in Canada, and Canada should either take law enforcement action to eliminate this illegal activity, or regulate these casinos. The requirements in relation to Recommendation 5 and 13 applicable to land-based casinos, real estate brokers and sales representatives and accountants do not meet the FATF standards. Canada has not implemented any specific AML/CFT measures concerning PEPs that are applicable to DNFBPs. There are no specific legislative or other enforceable obligations for DNFBPs to take measures to prevent the misuse of technological developments in ML/TF schemes. The DNFBPs are not required to have policies and procedures in place to address any specific risk associated with non face-to-face business relationships or transactions. Provisions in relation to record-keeping with regard to casinos, real estate brokers and sales representatives and accountants are not fully in line with the FATF standards. 
40. Because of limited staff resources, FINTRAC is not in a position to ensure an efficient monitoring of the effective application of AML/CFT legislation in the non-financial sectors captured by the PCMLTFA, especially in sectors/provinces where the primary regulators or SROs are not or insufficiently involved in AML/CFT compliance supervision. Canada should ensure that supervisory actions (especially on-site examinations) vis-à-vis casinos and more generally with regard to all DNFBPs are reinforced. With regard to DNFBPs, the sanction regime available to FINTRAC is currently inadequate but should be strengthened when administrative and monetary penalties are introduced in June 2008.

\section{Legal Persons and Arrangements \& Non-Profit Organisations}

41. Canada's corporate registry and information collection system does not adequately focus on obtaining information relating to the beneficial owner or controller of bodies corporate in Canada. The information collected and maintained (including changes in information) relates almost solely to persons and other corporations that are the immediate owners or controllers of a corporation through shareholdings. The federal corporate registrar should consider measures to mitigate the threat that may arise from the use of legal persons to perpetrate money laundering and terrorist financing. Canada should ensure that competent authorities have access to accurate and current information on the ultimate beneficial owners and controllers of all legal persons on a timely basis.

42. The Canada Business Corporations Act (CBCA) appears to allow for the ownership of corporations through the use of bearer shares, although it is likely that the number of bearer shares is limited. Nonetheless, there do not appear to be any special measures in place to ensure disclosure of beneficial owners of these shares in order to mitigate the ML or TF risk.

43. Except for the province of Quebec (where the fiducie is similar to the trust), all provinces are common law jurisdictions and have trust laws. Canada relies on the investigatory powers of law enforcement to obtain or have access to information concerning the beneficial ownership and control of trusts and fiducies. These powers are generally sound and widely used. In the case of trusts and fiducies, limited, partial information is available, and even where certain information is recorded by agencies such as CRA or FINTRAC, agencies can only share this information with law enforcement authorities in limited circumstances. Canada should implement measures to ensure that adequate, accurate and timely information is available to law enforcement authorities concerning the beneficial ownership and control of trusts and fiducie in Québec.

44. Canada has a well-established registration system for charities and has taken considerable steps to implement SR VIII. Registered charities include most organizations that raise and distribute funds for social or humanitarian purposes. Charities represent the most significant portion of the financial resources of the NPO sector and account for a substantial share of the sector's foreign activities. Nevertheless, in line with the FATF's risk-based approach, Canada should continue to monitor risks in other segments of the NPO sector.

\section{National and International Co-operation}

45. Canada has developed a large number of initiatives to improve co-operation mechanisms among the different domestic stakeholders taking part in the fight against money laundering and terrorist financing. The interagency cooperation between the FIU and law enforcement authorities is not fully effective and should be enhanced in order for Canada to optimise its capacity to investigate ML and TF cases. Canada should consider encouraging more bilateral contacts among agencies.

46. Almost all of the provisions of the Palermo and Vienna Conventions have been fully implemented, and only some minor technical deficiencies remain. Canada has extensive formal and limited informal 
means of providing mutual legal assistance (MLA) to requesting countries. Where the evidence can only be gathered pursuant to a court order, Canada's Mutual Legal Assistance in Criminal Matters Act ("MLACMA" or "the Act") is the domestic legislation that enables a Canadian court to issue orders compelling the production or authorizing the seizure of evidence at the request of a treaty partner. Canada has a centrally-coordinated MLA regime involving: the Department of Justice, Crown prosecutors, the Judiciary and, on occasion, law enforcement agents who execute Canadian courts' orders. Canada should focus on improving the effectiveness of the current regime and the collection of adequate data.

47. Under the MLACMA, Canada can directly enforce foreign orders for the restraint, seizure and forfeiture of assets on receipt of a request from a treaty partner or designated entity in line with the FATF requirements. However, in terms of implementation, there is limited evidence of effective confiscation assistance, and Canada should consider how this could be enhanced.

48. The money laundering and terrorist financing offences are extraditable offences under Canada's Extradition Act. The current legal provisions on extradition meet the FATF standards; however Canada should maintain better extradition request data, so as to better assess the timeliness of assistance.

49. In general, law enforcement authorities can engage in a wide range of international co-operation. FINTRAC can also share its intelligence with foreign counterparts. As the AML/CFT supervisor, FINTRAC has the legal capacity to exchange supervisory information with foreign regulators, but has not yet entered into any MOUs that will allow it to share in practice. On the other hand, OSFI can exchange compliance information with foreign counterparts.

\section{Other issues}

50. Overall, authorities seem to be well-equipped, staffed, resourced and trained. There are concerns about the availability of resources within FINTRAC to undertake a sufficient number of comprehensive examinations. The number of staff at FINTRAC dedicated to the analysis of ML/TF cases is also too low. Finally, the authorities in charge of processing MLA requests should acquire additional resources to fulfil their tasks.

51. Canada collects a large set of statistics although more comprehensive data should be gathered regarding ML investigations and sentencing, MLA and extradition requests. 


\section{Table 1. Ratings of Compliance with FATF Recommendations}

The rating of compliance vis-à-vis the FATF Recommendations should be made according to the four levels of compliance mentioned in the 2004 Methodology (Compliant (C), Largely Compliant (LC), Partially Compliant (PC), Non-Compliant (NC), or could, in exceptional cases, be marked as not applicable (NA).

\begin{tabular}{|l|l|}
\hline Compliant & The Recommendation is fully observed with respect to all essential criteria. \\
\hline $\begin{array}{l}\text { Largely } \\
\text { compliant }\end{array}$ & There are only minor shortcomings, with a large majority of the essential criteria being fully met. \\
\hline $\begin{array}{l}\text { Partially } \\
\text { compliant }\end{array}$ & The country has taken some substantive action and complies with some of the essential criteria. \\
\hline Non-compliant & There are major shortcomings, with a large majority of the essential criteria not being met. \\
\hline Not applicable & $\begin{array}{l}\text { A requirement or part of a requirement does not apply, due to the structural, legal or institutional } \\
\text { features of a country e.g. a particular type of financial institution does not exist in that country. }\end{array}$ \\
\hline
\end{tabular}

\begin{tabular}{|c|c|c|}
\hline Forty Recommendations & Rating & Summary of factors underlying rating \\
\hline \multicolumn{3}{|l|}{ Legal systems } \\
\hline 1. ML offence & LC & $\begin{array}{l}\text { - The ML offence does not cover all designated categories of predicate } \\
\text { offences (copyright related offences); } \\
\text { - Section } 462.31 \mathrm{ML} \text { offence contains a purposive element that is not } \\
\text { broad enough to meet the requirements of the Conventions or R.1; } \\
\text { - The number of convictions for Section } 462.31 \mathrm{ML} \text { is very low, as is the } \\
\text { percentage of convictions in comparison to charges laid. }\end{array}$ \\
\hline $\begin{array}{l}\text { 2. ML offence - mental element } \\
\text { and corporate liability }\end{array}$ & LC & $\begin{array}{l}\text { - The number of convictions for Section } 462.31 \mathrm{ML} \text { is very low; } \\
\text { - Due to the lack of data on } \mathrm{ML} \text { sentencing, is not possible to assess } \\
\text { whether natural and legal persons are subject to effective, proportionate } \\
\text { and dissuasive sanctions for ML. }\end{array}$ \\
\hline $\begin{array}{l}\text { 3. Confiscation and provisional } \\
\text { measures }\end{array}$ & LC & $\begin{array}{l}\text { - The fine in lieu forfeiture provision does not fully and effectively meets } \\
\text { the requirement for equivalent value provisions and does not apply to } \\
\text { property held by third parties; } \\
\text { - Based on the limited quantitative and qualitative information available, it } \\
\text { does not seem that the confiscation and seizure regime is fully effective, } \\
\text { particularly with respect to value based confiscation. }\end{array}$ \\
\hline \multicolumn{3}{|l|}{ Preventive measures } \\
\hline $\begin{array}{l}\text { 4. Secrecy laws consistent with the } \\
\text { Recommendations }\end{array}$ & C & - The Recommendation is fully met. \\
\hline 5. Customer due diligence & NC & $\begin{array}{l}\text { Scope issue } \\
\text { - the requirement to conduct CDD does not extend to all financial } \\
\text { institutions as defined by the FATF (notably financial leasing, factoring } \\
\text { and finance companies); } \\
\text { Numbered accounts } \\
\text { - Although numbered accounts are permissible and used, there is no } \\
\text { direct requirement to maintain them in such a way that full compliance } \\
\text { can be achieved with the FATF Recommendations; } \\
\text { When CDD is required } \\
\text { - There is no requirement to carry out CDD measures when there is a } \\
\text { suspicion of ML or TF and when financial institutions have doubts about } \\
\text { the veracity or adequacy of previously obtained CDD data; } \\
\text { - Customer identification for occasional transactions that are cross-border } \\
\text { wire transfers takes place for transactions above } \$ 3,000 \text {. This threshold }\end{array}$ \\
\hline
\end{tabular}




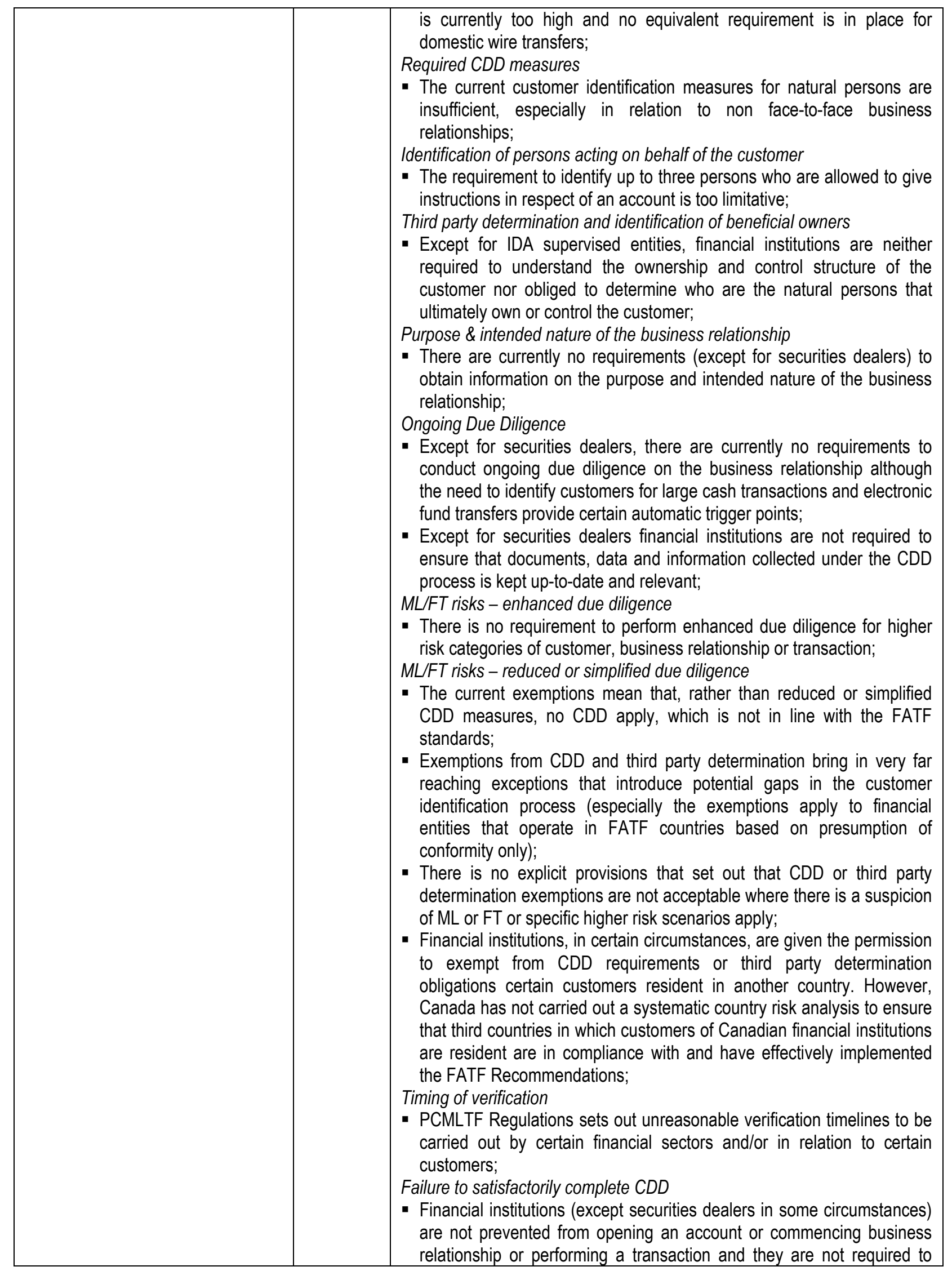




\begin{tabular}{|c|c|c|}
\hline & & $\begin{array}{l}\text { make a suspicious transaction report; } \\
\text { - In situations where the financial institution has already commenced a } \\
\text { business relationship but is unable to perform adequate CDD and } \\
\text { establish beneficial ownership, there is no requirement to terminate the } \\
\text { business relationship and to consider making a suspicious transaction } \\
\text { report. }\end{array}$ \\
\hline 6. Politically exposed persons & $\mathrm{NC}$ & $\begin{array}{l}\text { - There were no mandatory legislative or other enforceable requirements } \\
\text { in relation to PEPs at the time of the on-site visit. }\end{array}$ \\
\hline 7. Correspondent banking & PC & $\begin{array}{l}\text { - Financial entities are not required to assess the respondent institution's } \\
\text { AML/CFT controls and to ascertain that these controls are adequate } \\
\text { and effective; } \\
\text { - Financial institutions are not required to determine the reputation of the } \\
\text { foreign financial entity (other than take reasonable measures to } \\
\text { ascertain whether there are any civil or criminal penalties that have } \\
\text { been imposed on the foreign financial institution in respect of AML/CFT } \\
\text { requirements) and the quality of supervision of that entity; } \\
\text { - In the context of payable through accounts, the respondent entity is not } \\
\text { required to perform all the normal CDD obligations set out in } \\
\text { Recommendation } 5 \text { on its customers that have direct access to the } \\
\text { accounts of the correspondent institution in line with the FATF } \\
\text { standards; } \\
\text { - The effectiveness of the measures in place cannot yet be assessed. }\end{array}$ \\
\hline $\begin{array}{l}\text { 8. New technologies \& non face-to- } \\
\text { face business }\end{array}$ & NC & $\begin{array}{l}\text { - There are no specific legislative or other enforceable obligations } \\
\text { addressing the risks posed by the application of new technological } \\
\text { developments; } \\
\text { - Financial institutions are not required to have policies and procedures in } \\
\text { place to address any specific risk associated with non face-to-face } \\
\text { business relationships or transactions; } \\
\text { - No effective CDD procedures for non face-to-face customers are in } \\
\text { place. }\end{array}$ \\
\hline 9. Third parties and introducers & $\mathrm{NC}$ & $\begin{array}{l}\text { - In the only two scenarios where reliance on a third party or introduced } \\
\text { business is legally allowed without an agreement or arrangement, the } \\
\text { measures in place are insufficient to meet the FATF requirements; } \\
\text { - In addition to the two reliance on third parties/introduced business } \\
\text { scenarios contemplated by the Regulations, the financial sector uses } \\
\text { introduced business mechanisms as a business practice. However, no } \\
\text { specific requirements as set out in Recommendation } 9 \text { apply to these } \\
\text { scenarios. }\end{array}$ \\
\hline 10. Record keeping & LC & $\begin{array}{l}\text { Scope issue } \\
\text { - The record keeping requirement does not extend to all financial } \\
\text { institutions as defined by the FATF (notably financial leasing, factoring } \\
\text { and finance companies); } \\
\text { - Financial institutions must ensure that all records required to be kept } \\
\text { under the PCMLTFA can be provided within } 30 \text { days which does not } \\
\text { meet the requirement to make CDD records available on a timely basis } \\
\text { to competent authorities, especially in normal business circumstances. }\end{array}$ \\
\hline 11. Unusual transactions & PC & $\begin{array}{l}\text { - There is no explicit nor enforceable requirement for financial institutions } \\
\text { to examine all complex, unusual large transactions under the current } \\
\text { legislation (except for IDA members). Except for IDA members, the } \\
\text { monitoring obligation is implied and indirect (it flows from reporting } \\
\text { suspicious transactions, large international electronic funds transfer and } \\
\text { large cash transactions) and it does not cover the full range of } \\
\text { monitoring situations as stipulated in Recommendation 11; } \\
\text { - There is no explicit requirement to examine the background and } \\
\text { purpose of these unusual transactions (except for IDA members); } \\
\text { - There is no requirement to keep record of financial institutions' findings }\end{array}$ \\
\hline
\end{tabular}




\begin{tabular}{|c|c|c|}
\hline & & in relation to complex, unusual large or unusual patterns of transactions. \\
\hline 12. DNFBP - R.5, 6, 8-11 & NC & 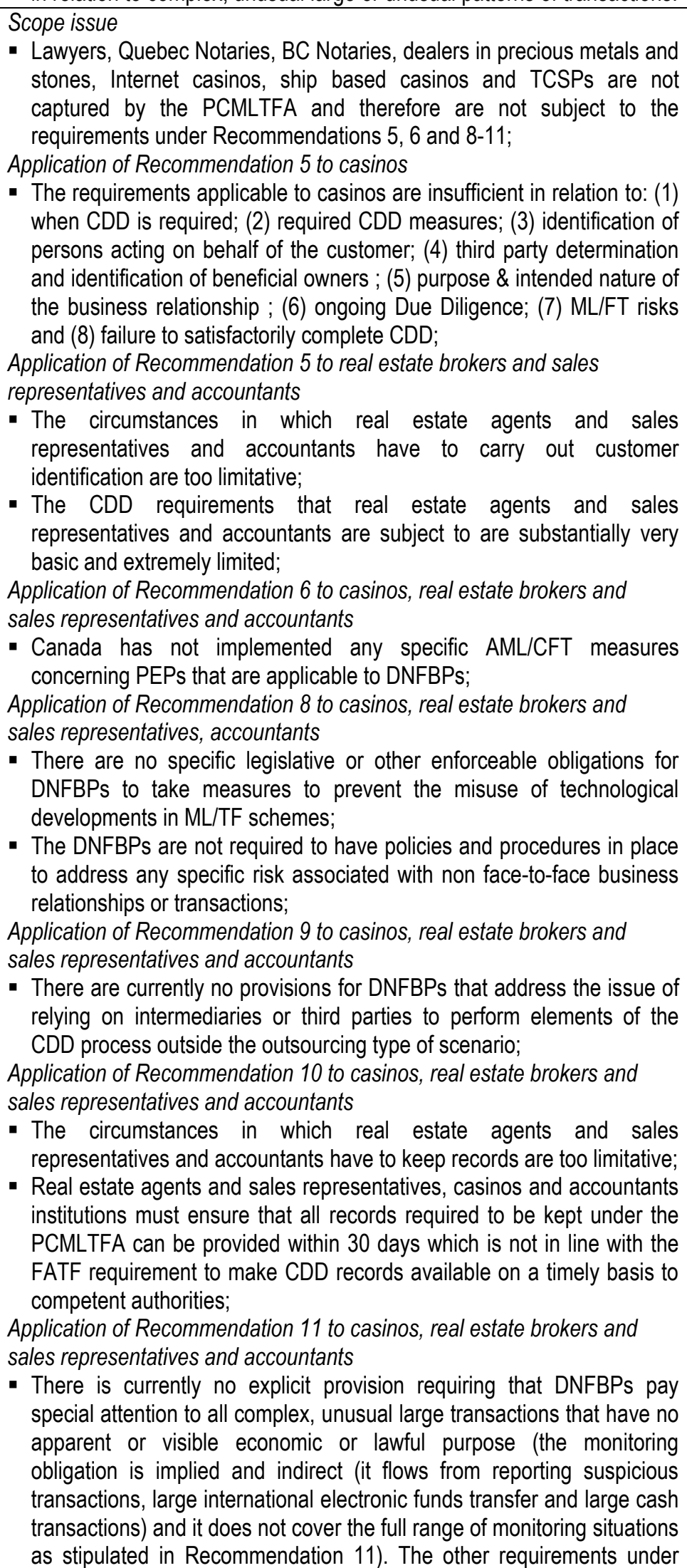 \\
\hline
\end{tabular}




\begin{tabular}{|c|c|c|}
\hline & & Recommendation 11 are not met either. \\
\hline 13. Suspicious transaction reporting & LC & $\begin{array}{l}\text { - Some financial institutions as defined by the FATF (especially financial } \\
\text { leasing, finance companies, providers of e-money) are not covered by } \\
\text { the obligation to report; } \\
\text { - There is no requirement to report attempted transactions; } \\
\text { - The low numbers of STRs sent by certain financial sectors raise } \\
\text { concerns in relation to the effectiveness of the reporting system. }\end{array}$ \\
\hline 14. Protection \& no tipping-off & C & - The Recommendation is fully met. \\
\hline $\begin{array}{l}\text { 15. Internal controls, compliance \& } \\
\text { audit }\end{array}$ & LC & $\begin{array}{l}\text { - The requirement for internal controls does not extend to all financial } \\
\text { institutions as defined by the FATF (notably financial leasing, factoring } \\
\text { and finance companies); } \\
\text { - There is no mandatory explicit requirement to maintain up to date } \\
\text { internal procedures, policies and controls and such policies do not } \\
\text { include the detection of unusual and suspicious transactions; } \\
\text { - There is no explicit requirement to ensure that the AML/CFT compliance } \\
\text { officer has a timely access to customer identification data and other } \\
\text { CDD information, transactions records and other relevant information; } \\
\text { - There is no mandatory requirement for an independent audit function to } \\
\text { test AML/CFT regime compliance for small financial institutions } \\
\text { (including some MSBs) for which a simple self-assessment is admitted; } \\
\text { - There is no general requirement concerning screening procedures } \\
\text { when hiring employees. }\end{array}$ \\
\hline 16. DNFBP - R.13-15 \& 21 & $\mathrm{NC}$ & $\begin{array}{l}\text { Scope issue } \\
\text { - Lawyers, Quebec Notaries, BC Notaries, dealers in precious metals and } \\
\text { stones, Internet casinos, ship based casinos and TCSPs are not } \\
\text { captured by the PCMLTFA and therefore are not subject to the } \\
\text { suspicious transactions reporting requirements; } \\
\text { Application of Recommendation } 13 \text { to casinos, real estate brokers and } \\
\text { sales representatives and accountants/accountant firms } \\
\text { - The circumstances in which real estate agents and sales } \\
\text { representatives and accountants have to report suspicious transactions } \\
\text { under the PCMLTFA are too limited; } \\
\text { - Attempted transactions are not yet covered by the Suspicious } \\
\text { Transaction Reporting requirement; } \\
\text { - The relatively low numbers of STRs sent by real estate agents/sales } \\
\text { representatives and accountants raise significant concerns in relation to } \\
\text { the effectiveness of the reporting system in these sectors; } \\
\text { Application of Recommendation } 15 \text { to casinos, real estate brokers and } \\
\text { sales representatives and accountants/accountant firms } \\
\text { - There is no explicit requirement to: (1) keep up to date internal } \\
\text { procedures, (2) have policies to monitor for and detect unusual and } \\
\text { suspicious transactions and (3) ensure that the AML/CFT compliance } \\
\text { officer has timely access to customer identification data and other CDD } \\
\text { information, transactions records and other relevant information; } \\
\text { - There is no mandatory requirement for an independent audit function to } \\
\text { test AML/CFT regime compliance; } \\
\text { - Except for casinos, there are no requirements concerning screening } \\
\text { procedures when hiring employees. } \\
\text { Application of Recommendation } 21 \text { to casinos, real estate brokers and } \\
\text { sales representatives and accountants/accountant firms } \\
\text { - There is no general enforceable requirement for DNFBPs to give } \\
\text { special attention to transactions or business relationships connected } \\
\text { with persons from or in countries which do not or insufficiently apply the } \\
\text { FATF Recommendations but only through general guidance or } \\
\text { advisories sent on a case by case basis; } \\
\text { - There are no effective measures in place whereby DNFBPs are advised }\end{array}$ \\
\hline
\end{tabular}




\begin{tabular}{|c|c|c|}
\hline & & $\begin{array}{l}\text { of other countries that have specific weaknesses in their AML/CFT } \\
\text { systems; } \\
\text { - There is no requirement to examine the background and purpose of } \\
\text { these transactions and to document the related findings. }\end{array}$ \\
\hline 17. Sanctions & PC & $\begin{array}{l}\text { - With the exceptions of OSFI and IDA regulated institutions, only criminal } \\
\text { sanctions are available to FINTRAC under the PCMLTFA for all other } \\
\text { types of financial institutions and these are only applicable for the most } \\
\text { serious failures, and need to be proved to the criminal standard; } \\
\text { - OSFI only uses a limited range of actions/sanctions in the AML/CFT } \\
\text { context (namely supervisory letters and in a limited number of cases, } \\
\text { staging); } \\
\text { - The lack of effective sanctions applied in cases of major deficiencies } \\
\text { raises real concern in terms of effectiveness of the sanction regime, } \\
\text { particularly taking into account that only one criminal sanction and a } \\
\text { very limited number of administrative sanctions have been applied. }\end{array}$ \\
\hline 18. Shell banks & LC & $\begin{array}{l}\text { - Financial entities are not required to terminate business relationships } \\
\text { with shell banks, nor with any foreign financial institution that has, } \\
\text { directly or indirectly, correspondent banking relationships with shell } \\
\text { banks; } \\
\text { - The effectiveness of the measures in place cannot yet be assessed. }\end{array}$ \\
\hline 19. Other forms of reporting & $C$ & - The Recommendation is fully met. \\
\hline $\begin{array}{l}\text { 20. Other NFBP \& secure } \\
\text { transaction techniques }\end{array}$ & C & - The Recommendation is fully met. \\
\hline $\begin{array}{l}\text { 21. Special attention for higher risk } \\
\text { countries }\end{array}$ & PC & $\begin{array}{l}\text { - There is no general enforceable requirement for financial institutions to } \\
\text { give special attention to transactions or business relationships } \\
\text { connected with persons from or in countries which do not or } \\
\text { insufficiently apply the FATF Recommendations; } \\
\text { - There are no effective measures in place whereby financial institutions } \\
\text { are advised of other countries that have specific weaknesses in their } \\
\text { AML/CFT systems; } \\
\text { - There is no requirement to examine the background and purpose of } \\
\text { these transactions and to document the related findings. }\end{array}$ \\
\hline $\begin{array}{l}\text { 22. Foreign branches \& } \\
\text { subsidiaries }\end{array}$ & NC & $\begin{array}{l}\text { - Currently, the PCMLTFA and PCMLTF Regulations contain no explicit } \\
\text { enforceable provision requiring financial institutions to ensure that their } \\
\text { foreign branches and subsidiaries observe AML/CFT measures } \\
\text { consistent with home country requirements although foreign branches } \\
\text { of Canadian financial institutions are Canadian entities under the Bank } \\
\text { Act and the Insurance Companies Act that are subject to Canadian } \\
\text { laws; } \\
\text { - There is no requirement that particular attention be paid to branches } \\
\text { and subsidiaries in countries which do not or insufficiently apply the } \\
\text { FATF Recommendations; } \\
\text { - There is no legal obligation in the PCMLTFA and PCMLTF Regulations } \\
\text { that, where the minimum AML/CFT requirements of the home and host } \\
\text { countries differ, branches and subsidiaries in host countries are } \\
\text { required to apply the higher standard, to the extent that local (i.e. host } \\
\text { country) laws and regulations permit; } \\
\text { - There is no requirement that financial institutions be required to inform } \\
\text { their home country supervisor when a foreign branch or subsidiary is } \\
\text { unable to observe appropriate AML/CFT measures because this is } \\
\text { prohibited by local (i.e. host country) laws, regulations or other } \\
\text { measures. }\end{array}$ \\
\hline $\begin{array}{l}\text { 23. Regulation, supervision and } \\
\text { monitoring }\end{array}$ & PC & $\begin{array}{l}\text { - Exclusion from the AML/CFT regime of certain financial sectors (such } \\
\text { as financial leasing, factoring, finance companies, etc.) without proper } \\
\text { risk assessments; } \\
\text { - For the financial institutions subject to the PCMLTFA, there is a very }\end{array}$ \\
\hline
\end{tabular}




\begin{tabular}{|c|c|c|}
\hline & & $\begin{array}{l}\text { unequal level of supervision of AML/CFT compliance, with certain } \\
\text { categories of financial institution appearing to be insufficiently controlled } \\
\text { (MSBs, certain credit unions/caisses populaires, life insurance } \\
\text { intermediaries...). This is due to the limited staff resources of FINTRAC } \\
\text { dedicated to on-site assessments compared to the high number of } \\
\text { reporting entities, which has not always been compensated by the } \\
\text { involvement of the primary prudential regulators in AML/CFT issues; } \\
\text { - "Fit and proper" requirements are not comprehensive; } \\
\text { - At the time of the on-site visit, there was no specific obligation for FRFIs } \\
\text { to implement screening procedures for persons who are hired, or } \\
\text { appointed to the Board, after the initial incorporation or authorisation } \\
\text { procedures are concluded; }\end{array}$ \\
\hline $\begin{array}{l}\text { 24. DNFBP - regulation, } \\
\text { supervision and monitoring }\end{array}$ & $\mathrm{NC}$ & $\begin{array}{l}\text { Scope issue } \\
\text { - Lawyers, Quebec Notaries, BC Notaries, dealers in precious metals and } \\
\text { stones, Internet casinos, ship based casinos and TCSPs are not } \\
\text { captured by the PCMLTFA and not subject to FINTRAC supervision; } \\
\text { Supervision of casinos } \\
\text { - The sanction regime available to FINTRAC is currently inadequate (see } \\
\text { conclusions in relation to Rec. 17). Provincial regulators may have } \\
\text { administrative sanctions at their disposal but there is no evidence that } \\
\text { these are dissuasive, effective and proportionate, since no data or } \\
\text { statistics regarding sanctions taken by these regulators on the grounds } \\
\text { of AML/CFT non-compliance issues have been made available to the } \\
\text { assessment team; } \\
\text { Supervision of other DNFBPs } \\
\text { - Limited staff resources deprives FINTRAC from closely and efficiently } \\
\text { monitoring DNFBPs compliance with the PCMLTFA requirements } \\
\text { especially in sectors/provinces where the primary regulators or SROs } \\
\text { are not or insufficiently involved in AML/CFT compliance supervision; } \\
\text { - The sanction regime available to FINTRAC is currently inadequate (see } \\
\text { conclusions in relation to Rec. 17). Provincial regulators may have } \\
\text { administrative sanctions at their disposal but there is no evidence that } \\
\text { these are dissuasive, effective and proportionate, since no data or } \\
\text { statistics regarding sanctions taken by these regulators on the ground of } \\
\text { AML/CFT non-compliance issues have been made available to the } \\
\text { assessment team. }\end{array}$ \\
\hline 25. Guidelines \& Feedback & LC & $\begin{array}{l}\text { - There is a lack of specific guidelines intended for sectors such as life } \\
\text { insurance companies and intermediaries; } \\
\text { - There is not enough general feedback given outside the large financial } \\
\text { institutions sector. }\end{array}$ \\
\hline \multicolumn{3}{|c|}{ Institutional and other measures } \\
\hline 26. The FIU & $\mathrm{PC}$ & $\begin{array}{l}\text { - FINTRAC has insufficient access to intelligence information from } \\
\text { administrative and other authorities (especially from CRA, CSIS and } \\
\text { Customs); } \\
\text { - FINTRAC is not allowed by the PCMLTFA to gather additional financial } \\
\text { information from reporting entities; } \\
\text { - Effectiveness: (1) the number of staff dedicated to the analysis of } \\
\text { potential ML/FT cases is low especially in comparison with the amount } \\
\text { of reports coming in, which may have an impact on the number of cases } \\
\text { that FINTRAC generate; (2) feedback from law enforcement authorities } \\
\text { outlines the relatively limited added value of FINTRAC disclosures in law } \\
\text { enforcement investigations; (3) the timeliness of FINTRAC disclosures } \\
\text { to law enforcement authorities was raised as an issue at the time of the } \\
\text { on-site visit; (4) } 80 \% \text { of the disclosures made by FINTRAC result from } \\
\text { voluntary information from law enforcement; only } 20 \% \text { result from STRs }\end{array}$ \\
\hline
\end{tabular}




\begin{tabular}{|c|c|c|}
\hline & & $\begin{array}{l}\text { which raises serious concerns with respect to the capability of FINTRAC } \\
\text { to generate ML/TF cases on the basis of STRs or other reports it } \\
\text { receives from the private sector; (5) so far, very few if any convictions } \\
\text { for ML or TF have resulted from a FINTRAC disclosure which is an } \\
\text { additional factor to consider when looking at FINTRAC's ability to } \\
\text { produce intelligence to be used in criminal investigations and } \\
\text { prosecutions. }\end{array}$ \\
\hline 27. Law enforcement authorities & LC & $\begin{array}{l}\text { - The RCMP lacks the resources that would allow it to focus on a larger } \\
\text { spectrum of ML/TF investigations. }\end{array}$ \\
\hline $\begin{array}{l}\text { 28. Powers of competent } \\
\text { authorities }\end{array}$ & C & - The Recommendation is fully met. \\
\hline 29. Supervisors & LC & - FINTRAC has no power to impose administrative sanctions. \\
\hline $\begin{array}{l}\text { 30. Resources, integrity and } \\
\text { training }\end{array}$ & PC & $\begin{array}{l}\text { In relation to the FIU: } \\
\text { - The number of staff dedicated to the analysis of ML/TF cases is too low, } \\
\text { especially considering the amount of reports coming in; } \\
\text { In relation to law enforcement agencies: } \\
\text { - The RCMP lacks resources to properly undertake ML/TF investigations; } \\
\text { In relation to the Department of Justice } \\
\text { - There seems to be very little if any coordinated or sophisticated training } \\
\text { efforts in the forfeiture area; } \\
\text { - The authorities in charge of processing MLA requests lack resources; } \\
\text { In relation to prosecution agencies: } \\
\text { - Insufficient training is provided for combating ML and TF; } \\
\text { In relation to supervisors: } \\
\text { - FINTRAC current internal organisation and resources dedicated to } \\
\text { supervision are insufficient to allow it to perform its compliance function } \\
\text { effectively. }\end{array}$ \\
\hline 31. National co-operation & LC & $\begin{array}{l}\text { - Interagency cooperation between the FIU and law enforcement } \\
\text { authorities is not fully effective and needs to be enhanced. }\end{array}$ \\
\hline 32. Statistics & LC & $\begin{array}{l}\text { - Incomplete statistics are kept in relation to ML investigations; } \\
\text { - Incomplete statistics are kept in relation to ML sentencing; } \\
\text { - Statistics on confiscation are incomplete; } \\
\text { - There is no data available on the time requested to respond to } \\
\text { extradition and MLA requests; } \\
\text { - No statistics are kept by OSFI on the time to respond to a request } \\
\text { initiated by its counterparts. }\end{array}$ \\
\hline $\begin{array}{l}\text { 33. Legal persons - beneficial } \\
\text { owners }\end{array}$ & NC & $\begin{array}{l}\text { - There is no requirement to ensure adequate transparency, for instance } \\
\text { there is no obligation that information on the beneficial ownership of } \\
\text { shares in legal persons is required to be collected by either the } \\
\text { corporate registry, within corporate records held by legal persons or by } \\
\text { lawyers, accountants or TCSPs; } \\
\text { - While law enforcement and other authorities have sufficient powers, } \\
\text { those powers are not adequate to ensure the existence of adequate, } \\
\text { accurate and timely information on the beneficial ownership of legal } \\
\text { persons, which can be accessed or obtained in a timely fashion by } \\
\text { competent authorities; } \\
\text { - There are no measures to ensure that bearer shares are not misused for } \\
\text { ML, particularly for private corporations. }\end{array}$ \\
\hline $\begin{array}{l}\text { 34. Legal arrangements - beneficial } \\
\text { owners }\end{array}$ & PC & $\begin{array}{l}\text { - There are limited and indirect legal requirements to obtain, verify, or } \\
\text { retain information on the beneficial ownership and control of trusts and } \\
\text { fiducie in Québec; } \\
\text { - While the investigative powers are generally sound and widely used, } \\
\text { there is minimal information that is adequate, accurate and timely } \\
\text { concerning the beneficial owners of trusts and fiducie in Québec that } \\
\text { can be obtained or accessed by the competent authorities in a timely }\end{array}$ \\
\hline
\end{tabular}




\begin{tabular}{|c|c|c|}
\hline & & $\begin{array}{l}\text { fashion. Where some information is held, such as by CRA, there are } \\
\text { limits on the circumstances in which information on trusts can be } \\
\text { shared. }\end{array}$ \\
\hline \multicolumn{3}{|l|}{ International Co-operation } \\
\hline 35. Conventions & LC & $\begin{array}{l}\text { Implementation of the Palermo and Vienna Conventions: } \\
\text { - Canada has ratified the Palermo and Vienna Conventions and } \\
\text { implemented them with some omissions however (the ML offence does } \\
\text { not cover all required categories of predicate offences and Section } \\
462.31 \mathrm{ML} \text { offence contains a purposive element that is not broad } \\
\text { enough to meet the requirements of the Conventions); } \\
\text { Implementation of the CFT Convention: } \\
\text { - Article } 18(1)(\mathrm{b}) \text { of the Convention, which requires countries to implement } \\
\text { efficient measures to identify customers in whose interest accounts are } \\
\text { opened is insufficiently implemented. Canada's implementation of } \\
\text { Recommendation } 5 \text { does not include adequate measures to ascertain } \\
\text { the identity of beneficial owners. }\end{array}$ \\
\hline 36. Mutual legal assistance (MLA) & LC & $\begin{array}{l}\text { - There are concerns about the ability of Canada to handle MLA requests } \\
\text { in a timely and effective manner and effectiveness of the current regime } \\
\text { cannot be demonstrated due to the lack of adequate data. }\end{array}$ \\
\hline 37. Dual criminality & C & - The Recommendation is fully met. \\
\hline $\begin{array}{l}\text { 38. MLA on confiscation and } \\
\text { freezing }\end{array}$ & LC & $\begin{array}{l}\text { - There are doubts about the effectiveness of the measures in place } \\
\text { under Recommendation 38: there is limited evidence of effective } \\
\text { confiscation assistance as only four cases have been successful in last } \\
5 \text { years and international sharing statistics indicate that while asset } \\
\text { sharing with foreign states is possible, it rarely occurs. Canada executes } \\
\text { requests to enforce corresponding value judgments as fines, which has } \\
\text { limitations and cannot be enforced against property held by third parties. }\end{array}$ \\
\hline 39. Extradition & LC & $\begin{array}{l}\text { - Insufficient statistical data was provided to make a thorough } \\
\text { assessment, particularly the assessment of the delay element, but even } \\
\text { the limited data provided indicates that obtaining extradition from } \\
\text { Canada quickly may be difficult. }\end{array}$ \\
\hline 40. Other forms of co-operation & LC & $\begin{array}{l}\text { FINTRAC as a supervisory authority } \\
\text { - FINTRAC has the legal capacity to exchange information with foreign } \\
\text { counterparts but has not yet put the arrangements and agreements in } \\
\text { place. }\end{array}$ \\
\hline Nine Special Recommendations & Rating & Summary of factors underlying rating \\
\hline $\begin{array}{ll}\text { SR.I Implement UN instruments } \\
\text { I }\end{array}$ & LC & $\begin{array}{l}\text { Implementation of the CFT Convention: } \\
\text { - Article } 18(1)(b) \text { of the Convention, which requires countries to implement } \\
\text { efficient measures to identify customers in whose interest accounts are } \\
\text { opened is insufficiently implemented. Canada's implementation of } \\
\text { Recommendation } 5 \text { does not include adequate measures to ascertain } \\
\text { the identity of beneficial owners. }\end{array}$ \\
\hline $\begin{array}{l}\text { SR.II Criminalise terrorist } \\
\text { financing }\end{array}$ & LC & $\begin{array}{l}\text { - The lack of any TF convictions and the very limited number of } \\
\text { prosecutions shows that the offence has not yet been fully and } \\
\text { effectively used. }\end{array}$ \\
\hline $\begin{array}{l}\text { SR.III Freeze and confiscate } \\
\text { terrorist assets }\end{array}$ & LC & $\begin{array}{l}\text { - The actions taken to communicate the names of listed persons or } \\
\text { entities do not cover all types of financial institutions and the lists are } \\
\text { not effectively communicated to other types of asset holders; } \\
\text { - With the exception of guidance given to federally regulated financial } \\
\text { institutions (and copied to provincial regulators/SROs), Canada has } \\
\text { issued insufficient guidance to other financial institutions and DNFBP } \\
\text { that may be holding funds of other assets concerning their obligations in } \\
\text { taking action under freezing mechanisms. This may have an impact on } \\
\text { Canada's ability to freeze terrorist funds or other assets for such entities }\end{array}$ \\
\hline
\end{tabular}




\begin{tabular}{|c|c|c|}
\hline & & $\begin{array}{l}\text { without delay; } \\
\text { - The existing measures to effectively monitor the compliance with the } \\
\text { legislation governing the obligations under SRIII are insufficient (except } \\
\text { for federally regulated financial institutions supervised by OSFI). }\end{array}$ \\
\hline $\begin{array}{l}\text { SR.IV Suspicious transaction } \\
\text { reporting }\end{array}$ & LC & $\begin{array}{l}\text { - Some financial institutions as defined by the FATF (especially financial } \\
\text { leasing, finance companies, providers of e-money) are not covered by } \\
\text { the obligation to report; } \\
\text { - There is no requirement to report attempted transactions. }\end{array}$ \\
\hline SR.V International co-operation & LC & $\begin{array}{l}\text { Regarding compliance with Recommendation } 38 \\
\text { - All elements missing in R. } 38 \text { are missing for SR.V; } \\
\text { - There are concerns about the ability of Canada to handle MLA requests } \\
\text { in a timely and effective manner and effectiveness of the current regime } \\
\text { cannot be demonstrated due to the lack of adequate data. } \\
\text { Regarding compliance with Recommendation } 39 \\
\text { - No meaningful statistical data provided to assess delay element } \\
\text { (effectiveness issue). } \\
\text { Regarding compliance with Recommendation } 40 \\
\text { FINTRAC as a supervisory authority } \\
\text { - FINTRAC has the legal capacity to exchange information with foreign } \\
\text { counterparts but has not yet put the arrangements and agreements in } \\
\text { place. }\end{array}$ \\
\hline $\begin{array}{l}\mathrm{SR} \mathrm{VI} \quad \mathrm{AML} \text { requirements for } \\
\text { money/value transfer services }\end{array}$ & NC & $\begin{array}{l}\text { - There is no registration regime for MSBs as contemplated by SR Vl; } \\
\text { - Overall, requirements and implementation of Recommendations 4-11, } \\
21-23 \text { and SR. VII is inadequate which has a significant negative impact } \\
\text { on the effectiveness of AML/CFT measures for money transmission } \\
\text { services.; } \\
\text { - MSBs are not required to maintain a list of their agents; } \\
\text { - The sanction regime available to FINTRAC and applicable to MSBs is } \\
\text { not effective, proportionate and dissuasive. }\end{array}$ \\
\hline SR VII Wire transfer rules & NC & - Canada has not implemented SRVII. \\
\hline SR.VIII Non-profit organisations & LC & $\begin{array}{l}\text { - The existing co-ordination mechanisms between competent authorities, } \\
\text { especially between the CRA and the parties responsible for listing and } \\
\text { freezing applications is insufficient to fully address the risk in some } \\
\text { segments of the NPO sector. }\end{array}$ \\
\hline $\begin{array}{l}\text { SR.IX Cross Border Declaration \& } \\
\text { Disclosure }\end{array}$ & C & - The Recommendation is fully met. \\
\hline
\end{tabular}


Table 2: Recommended Action Plan to Improve the AML/CFT System

\begin{tabular}{|c|c|}
\hline AML/CFT System & Recommended Action (listed in order of priority) \\
\hline \multicolumn{2}{|l|}{ 1. General } \\
\hline \multicolumn{2}{|c|}{ 2. Legal System and Related Institutional Measures } \\
\hline Criminalisation of Money Laundering (R.1 \&, 2) & $\begin{array}{l}\text { - Canada should cover all designated categories of predicate offences; } \\
\text { - Canada should amend Section } 462.31 \mathrm{ML} \text { offence (in relation to the intent } \\
\text { mental element) in order to fully met the requirements of the Conventions or } \\
\text { - Recommendation } 1 \text {; } \\
\text { - Canada should ensure that the statutes available for countering ML are } \\
\text { effectively used; } \\
\text { - Canada should develop a more proactive approach to prosecuting the specific } \\
\text { money laundering charge under } s .462 .31 \text {. }\end{array}$ \\
\hline Criminalisation of Terrorist Financing (SR.II) & $\begin{array}{l}\text { - Canada should pay attention to the overall effectiveness of the TF offence and } \\
\text { regime and ensure that the TF offence is effectively used. }\end{array}$ \\
\hline $\begin{array}{l}\text { Confiscation, freezing and seizing of proceeds } \\
\text { of crime (R.3) }\end{array}$ & $\begin{array}{l}\text { - Canada should review the fine in lieu forfeiture provision to be in line with the } \\
\text { FATF requirements; } \\
\text { - Canada should ensure that the confiscation and seizure regime is fully } \\
\text { effective, particularly with respect to value based confiscation. }\end{array}$ \\
\hline $\begin{array}{l}\text { Freezing of funds used for terrorist financing } \\
\text { (SR.III) }\end{array}$ & $\begin{array}{l}\text { - There needs to be more communication on listed persons provided to certain } \\
\text { categories of financial institutions and other potential asset holders as well } \\
\text { more clear and practical guidance to reporting entities (including DNFBPs and } \\
\text { MSBs) that may be holding targeted funds or other assets concerning their } \\
\text { obligations in taking action under freezing mechanisms; } \\
\text { - Canada should enhance the existing measures to monitor the compliance with } \\
\text { the legislation governing the obligations under SRIII (except for federally } \\
\text { regulated financial institutions supervised by OSFI). }\end{array}$ \\
\hline $\begin{array}{l}\text { The Financial Intelligence Unit and its functions } \\
\text { (R.26 \& 30) }\end{array}$ & $\begin{array}{l}\text { - FINTRAC should be able to obtain additional financial information from the } \\
\text { reporting entities, especially during the analytical process; } \\
\text { - FINTRAC should be authorised to have access to more intelligence data from } \\
\text { CSIS, CRA and the Canadian Customs Agency to reinforce its analytical } \\
\text { work. } \\
\text { - Canada should examine FINTRAC effectiveness in disclosing ML/TF cases to } \\
\text { law enforcement authorities; } \\
\text { - Canada should ensure that FINTRAC has sufficient analysts that are in } \\
\text { charge of developing ML/TF cases and processing disclosures to law } \\
\text { enforcement authorities for further investigations. }\end{array}$ \\
\hline $\begin{array}{l}\text { Law enforcement, prosecution and other } \\
\text { competent authorities (R.27 \& 28) }\end{array}$ & $\begin{array}{l}\text { - Canada should ensure that the RCMP gets sufficient resources that would } \\
\text { allow it to focus on a larger spectrum of ML/TF investigations. }\end{array}$ \\
\hline Cross Border declaration or disclosure (SR.IX) & - There are no recommendations for this section. \\
\hline \multicolumn{2}{|l|}{ 3. Preventive Measures - Financial Institutions } \\
\hline Risk of money laundering or terrorist financing & $\begin{array}{l}\text { - Canada should rely on a more comprehensive, thorough and formal risk } \\
\text { assessment process. The underlying principle should be that the financial } \\
\text { activities referred to in the FATF standards should be covered unless there is } \\
\text { a proven low risk of ML/TF. }\end{array}$ \\
\hline $\begin{array}{l}\text { Customer due diligence, including enhanced or } \\
\text { reduced measures (R.5 to } 8 \text { ) }\end{array}$ & $\begin{array}{l}\text { In relation to Recommendation 5: } \\
\text { - With regard to numbered or confidential accounts, Canada should consider } \\
\text { adopting detailed rules or guidance on the use of such accounts by financial }\end{array}$ \\
\hline
\end{tabular}




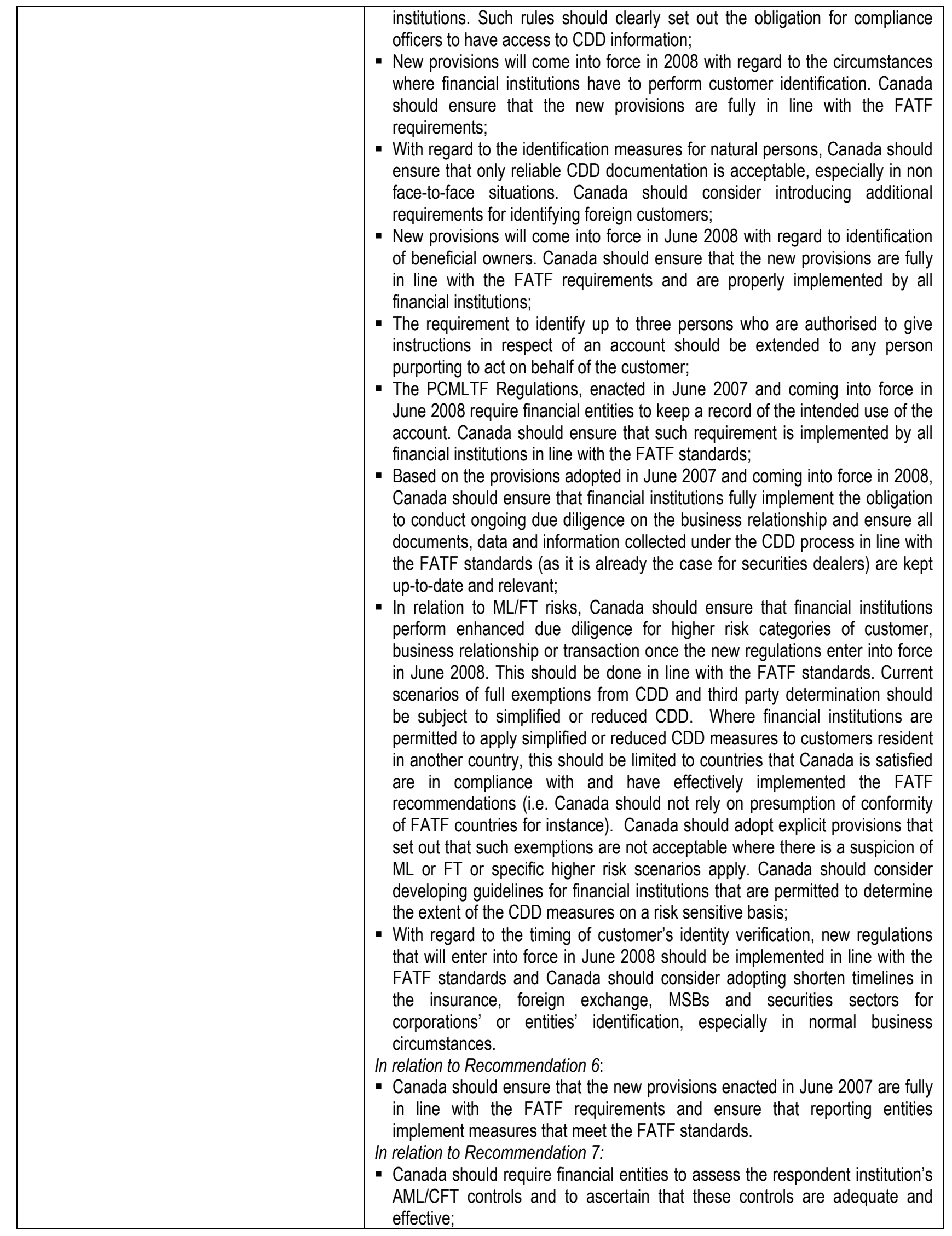




\begin{tabular}{|c|c|}
\hline & $\begin{array}{l}\text { - Institutions should also be required to determine the reputation of the foreign } \\
\text { financial entity (other than take reasonable measures to ascertain whether } \\
\text { there are any civil or criminal penalties that have been imposed on the foreign } \\
\text { financial institution in respect of AML/CFT requirements) and the quality of } \\
\text { supervision of that entity; } \\
\text { - In the context of payable through accounts, the respondent entity should be } \\
\text { required to perform all customer identification in line with the FATF standards; } \\
\text { - Canada should ensure that reporting entities implement measures that meet } \\
\text { the FATF standards. } \\
\text { In relation to Recommendation } 8 \text { : } \\
\text { - Canada should ensure that the new provisions enacted in June } 2007 \text { are fully } \\
\text { in line with the FATF requirements and ensure that reporting entities } \\
\text { implement measures that meet the FATF standards. }\end{array}$ \\
\hline Third parties and introduced business (R.9) & $\begin{array}{l}\text { - Since introduced business arrangements exist in Canada in other } \\
\text { circumstances than those captured by Sections } 56(2) \text { and } 57(5) \text { of the } \\
\text { PCMLTF Regulations, Canada should adopt provisions that address all } \\
\text { aspects of Recommendation } 9 \text { and ensure that financial institutions implement } \\
\text { them. }\end{array}$ \\
\hline $\begin{array}{l}\text { Financial institution secrecy or confidentiality } \\
\text { (R.4) }\end{array}$ & - There are no recommendations for this section. \\
\hline $\begin{array}{l}\text { Record keeping and wire transfer rules (R.10 \& } \\
\text { SR.VII) }\end{array}$ & $\begin{array}{l}\text { In relation with Recommendation 10: } \\
\text { - Canada should ensure that all types of transactions (including business } \\
\text { correspondence) carried out by financial institutions (except for IDA members) } \\
\text { are subject to proper record keeping requirements that permit their } \\
\text { reconstruction so as to provide, if necessary, evidence for prosecution of } \\
\text { criminal activity; } \\
\text { - Canada should ensure that all customer and transactions records and } \\
\text { information are available on a timely basis to domestic competent authorities. } \\
\text { In relation with SRVII: } \\
\text { - Canada should ensure that the new provisions enacted in December } 2006 \\
\text { and coming into force in June } 2008 \text { are fully in line with the FATF } \\
\text { requirements and ensure that reporting entities implement measures that } \\
\text { meet the FATF standards; } \\
\text { - Canada should ensure that the wire transfers operated by casinos outside the } \\
\text { banking network are subject to equivalent requirements. }\end{array}$ \\
\hline $\begin{array}{l}\text { Monitoring of transactions and relationships } \\
\text { (R.11\& 21) }\end{array}$ & $\begin{array}{l}\text { In relation with Recommendation 11: } \\
\text { - Canada should ensure that the new provisions enacted in June } 2007 \text { are fully } \\
\text { in line with the FATF requirements and ensure that reporting entities } \\
\text { implement measures that meet the FATF standards. } \\
\text { In relation with Recommendation 21: } \\
\text { - The requirement to give special attention to business relationships or } \\
\text { transactions with persons from or in countries which do not or insufficiently } \\
\text { apply the FATF Recommendations should be included in an enforceable legal } \\
\text { instrument applicable to all financial institutions; } \\
\text { - Effective measures should be put in place whereby financial institutions are } \\
\text { advised of other countries that have specific weaknesses in their AML/CFT } \\
\text { systems. This should be completed by a provision requiring that the } \\
\text { background and purpose of such transactions having no apparent economic } \\
\text { or visible lawful purpose be examined and the findings documented. }\end{array}$ \\
\hline $\begin{array}{l}\text { Suspicious transaction reports and other } \\
\text { reporting (R.13-14, 19, } 25 \text { \& SR.IV) }\end{array}$ & $\begin{array}{l}\text { In relation with Recommendation } 13 \text { \& SRIV } \\
\text { - All financial institutions covered by the definition of the FATF should be } \\
\text { subject to the suspicious transactions reporting requirement unless a proven } \\
\text { low risk of ML and FT is established in the sectors that are currently } \\
\text { - exempted; } \\
\text { - Canada should ensure that the different categories of financial institutions }\end{array}$ \\
\hline
\end{tabular}




\begin{tabular}{|c|c|}
\hline & $\begin{array}{l}\text { contribute more equally to the total number of STRs received by FINTRAC } \\
\text { In relation with Recommendation } 14 \\
\text { - There are no recommendations for this section. } \\
\text { In relation with Recommendation } 19 \\
\text { - There are no recommendations for this section. } \\
\text { In relation with Recommendation } 25 \\
\text { - FINTRAC should develop more general feedback for smaller reporting } \\
\text { entities. }\end{array}$ \\
\hline $\begin{array}{l}\text { Internal controls, compliance, audit and foreign } \\
\text { branches (R.15 \& 22) }\end{array}$ & $\begin{array}{l}\text { In relation to Recommendation } 15 \\
\text { - The current requirements should be expanded, made more explicit and } \\
\text { enforceable, in particular (1) written policies and procedures should be } \\
\text { explicitly required, and should be kept up to date, and their minimum } \\
\text { mandatory content should include the detection of unusual and suspicious } \\
\text { transactions; (2) there should be an explicit requirement to ensure that the } \\
\text { AML/CFT compliance officer has a timely access to customer identification } \\
\text { data and other CDD information, transactions records and other relevant } \\
\text { information; (3) the requirement for an independent audit function (internal or } \\
\text { external) to test on a regular basis the compliance of the AML regime should } \\
\text { be strengthened for MSBs and small financial institutions, and made more } \\
\text { explicit generally; (4) Canada should impose screening procedures when } \\
\text { hiring employees for financial institutions } \\
\text { In relation to Recommendation } 22 \\
\text { - Canada should ensure that the provisions in relation to Recommendation } 22 \\
\text { that will enter into force in June } 2008 \text { are in line with the FATF requirements } \\
\text { and are properly implemented by all financial institutions. }\end{array}$ \\
\hline Shell banks (R.18) & $\begin{array}{l}\text { - Canada should adopt a requirement for financial entities to terminate business } \\
\text { relationships with shell banks as well as with any foreign financial institution } \\
\text { that has, directly or indirectly, correspondent banking relationships with shell } \\
\text { banks; } \\
\text { - Canada should ensure that the measures adopted in relation to shell banks } \\
\text { are fully implemented by financial institutions. }\end{array}$ \\
\hline $\begin{array}{l}\text { The supervisory and oversight system - } \\
\text { competent authorities and SROs } \\
\text { Role, functions, duties and powers (including } \\
\text { sanctions) (R.23, 30, 29, } 17 \text { \& 25) }\end{array}$ & $\begin{array}{l}\text { In relation to Recommendation } 17,23 \& 29 \\
\text { - Canada should ensure a proper and effective implementation of the regime of } \\
\text { administrative and monetary penalties and ensure that competent authorities } \\
\text { put in place effective, proportionate and dissuasive sanctions; } \\
\text { - Canada should implement a more equal level of supervision of AML/CFT } \\
\text { compliance vis-à-vis certain categories of financial institution (MSBs, certain } \\
\text { credit unions/caisses populaires, life insurance intermediaries...). } \\
\text { - Canada should ensure that "fit and proper" requirements are in place; } \\
\text { - Canada should adopt screening procedures for persons who are hired, or } \\
\text { appointed to the Board, after the initial incorporation or authorisation } \\
\text { procedures are concluded; } \\
\text { - Canada should implement the registration regime for MSBs. } \\
\text { In relation to Recommendation } 25 \\
\text { - Canada should provide more specific guidelines for sectors such as life } \\
\text { insurance companies and intermediaries. }\end{array}$ \\
\hline Money value transfer services (SR.VI) & $\begin{array}{l}\text { - Canada should ensure effective implementation of the registration system for } \\
\text { MSBs in force in June } 2008 \text { and ensure that the requirements applicable to } \\
\text { MSBs fully meet the FATF requirements }\end{array}$ \\
\hline \multicolumn{2}{|c|}{ 4. Preventive Measures -Non-Financial Businesses and Professions } \\
\hline $\begin{array}{l}\text { Customer due diligence and record-keeping } \\
\text { (R.12) }\end{array}$ & $\begin{array}{l}\text { - All DNFBPs as defined by the FATF should be subject to the AML/CFT } \\
\text { regime; } \\
\text { - The circumstances in which real estate agents and sales representatives and } \\
\text { accountants have to carry out customer identification and keep records should } \\
\text { be extended to be in line with the types of activities targeted under }\end{array}$ \\
\hline
\end{tabular}




\begin{tabular}{|c|c|}
\hline & $\begin{array}{l}\text { Recommendation 12; } \\
\text { In relation to Recommendation } 5 \text { : } \\
\text { - Canada should ensure that the entire set of requirements under } \\
\text { Recommendation } 5 \text { apply to all non-financial professions. } \\
\text { In relation to Recommendations } 6,8,9 \text { and } 11 \text { : } \\
\text { - Canada should require the non-financial professions to implement } \\
\text { requirements in relation to Recommendations } 6,8,9 \text { and } 11 \text {. } \\
\text { In relation to Recommendation } 10 \text { : } \\
\text { - Canada should ensure that all types of transactions carried out by the non- } \\
\text { financial professions are subject to proper record keeping requirement that } \\
\text { permits their reconstruction so as to provide, if necessary, evidence for } \\
\text { prosecution of criminal activity; } \\
\text { - Canada should ensure that all customer and transactions records and } \\
\text { information collected by the non-financial professions are available on a timely } \\
\text { basis to domestic competent authorities. }\end{array}$ \\
\hline Suspicious transaction reporting (R.16) & $\begin{array}{l}\text { In relation to Recommendation 13: } \\
\text { - All DNFBPs as defined by the FATF should be subject in Canada to the } \\
\text { suspicious transactions reporting requirement in all circumstances defined in } \\
\text { Recommendation 16; } \\
\text { In relation to Recommendation 15: } \\
\text { - The current requirements should be expanded, specified and enforced, } \\
\text { especially: (1) the policies and procedures should be required to be written } \\
\text { and their minimum mandatory content should include the detection of unusual } \\
\text { and suspicious transactions for all DNFBPs; (2) there should be a requirement } \\
\text { to ensure that the AML/CFT compliance officer has a timely access to } \\
\text { customer identification data and other CDD information, transactions records } \\
\text { and other relevant information; (3) the requirement for an independent audit } \\
\text { function (internal or external) to test on a regular basis the compliance of the } \\
\text { AML regime should be strengthened; (4) Canada should impose screening } \\
\text { procedures when hiring employees to DNFBPs. } \\
\text { In relation to Recommendation 21: } \\
\text { - The requirement to give special attention to business relationships or } \\
\text { transactions with persons from or in countries which do not or insufficiently } \\
\text { apply the FATF Recommendations should be included in an enforceable legal } \\
\text { instrument applicable to DNFBPs; } \\
\text { - Effective measures should be put in place whereby DNFBPs are advised of } \\
\text { other countries that have specific weaknesses in their AML/CFT systems } \\
\text { - Finally a provision should be introduced requiring that the background and } \\
\text { purpose of such transactions having no apparent economic or visible lawful } \\
\text { purpose be examined and the findings documented. }\end{array}$ \\
\hline $\begin{array}{l}\text { Regulation, supervision and monitoring (R.24- } \\
\text { 25) }\end{array}$ & $\begin{array}{l}\text { - All DNFBPs as defined by the FATF should be subject to the AML/CFT } \\
\text { regime; } \\
\text { - Canada should ensure that supervisory action (especially on-site } \\
\text { examinations) vis-à-vis casinos, but more importantly with respect to all other } \\
\text { DNFBPs is strongly reinforced; } \\
\text { - The role, functions and monitoring powers of other regulators and SROs in } \\
\text { ensuring compliance of DNFBPs with the AML/CFT requirements should be } \\
\text { clarified; } \\
\text { - Canada should consider revisiting the supervision issue as a whole and give } \\
\text { further consideration on whether FINTRAC should be the only authority in } \\
\text { charge of ensuring compliance with the AML/CFT requirements; } \\
\text { - The sanction regimes applicable to DNFBPs, including casinos, should be } \\
\text { reinforced and Canada should ensure that the sanctions available for failures } \\
\text { to apply AML/CFT requirements are effective, proportionate and dissuasive. }\end{array}$ \\
\hline Other designated non-financial & - There are no recommendations for this section. \\
\hline
\end{tabular}




\begin{tabular}{|c|c|}
\hline \multicolumn{2}{|l|}{ professions (R.20) } \\
\hline \multicolumn{2}{|c|}{ 5. Legal Persons and Arrangements \& Non-Profit Organisations } \\
\hline $\begin{array}{l}\text { Legal Persons - Access to beneficial } \\
\text { ownership and control information (R.33) }\end{array}$ & $\begin{array}{l}\text { - Canada should adopt further requirements to prevent the unlawful use of legal } \\
\text { persons in relation to ML and TF; } \\
\text { - Canada should ensure that competent authorities have access to accurate } \\
\text { and current information on the ultimate beneficial owners and controllers of all } \\
\text { legal persons on a timely basis; } \\
\text { - Canada should adopt measures to ensure that bearer shares are not misused } \\
\text { for ML, particularly for private corporations. }\end{array}$ \\
\hline $\begin{array}{l}\text { Legal Arrangements - Access to beneficial } \\
\text { ownership and control information (R.34) }\end{array}$ & $\begin{array}{l}\text { - Canada should ensure that competent authorities have access to accurate } \\
\text { and current information on the ultimate beneficial owners and controllers of all } \\
\text { legal arrangements on a timely basis; } \\
\text { - Canada should implement measures to ensure that adequate, accurate and } \\
\text { timely information is available to law enforcement authorities concerning the } \\
\text { beneficial ownership and control of trusts and fiducie in Québec. }\end{array}$ \\
\hline Non-profit organisations (SR.VIII) & $\begin{array}{l}\text { - Canada should improve the existing co-ordination mechanisms between } \\
\text { competent authorities, especially between the CRA and the parties } \\
\text { responsible for listing and freezing applications. }\end{array}$ \\
\hline \multicolumn{2}{|l|}{ 6. National and International Co-operation } \\
\hline National co-operation and coordination (R.31) & $\begin{array}{l}\text { - Canada should enhance interagency cooperation between the FIU and law } \\
\text { enforcement authorities. }\end{array}$ \\
\hline $\begin{array}{l}\text { The Conventions and UN Special Resolutions } \\
\text { (R.35 \& SR.I) }\end{array}$ & $\begin{array}{l}\text { - Canada should ensure that the ML offence does cover all designated } \\
\text { categories of predicate offences and Canada should consider removing the } \\
\text { purpose element from Section } 462.31 \text { of the CC to be in line with the UN } \\
\text { Conventions; } \\
\text { - Canada should enact stronger measures to customer identification so as to be } \\
\text { more compliant with Article } 18(1)(\text { b) of the CFT Convention. }\end{array}$ \\
\hline Mutual Legal Assistance (R.36-38, SR.V) & $\begin{array}{l}\text { - Canada should ensure that MLA requests are handled in a timely and } \\
\text { effective manner; } \\
\text { - Canada should consider ways to improve the mechanisms to respond to } \\
\text { foreign confiscation requests. }\end{array}$ \\
\hline Extradition (R.39, 37, SR.V) & $\begin{array}{l}\text { - Canada should ensure that extradition requests are handled in a timely and } \\
\text { effective manner. }\end{array}$ \\
\hline Other Forms of Co-operation (R.40, SR.V) & $\begin{array}{l}\text { - FINTRAC should rapidly enter into agreements with key supervisory } \\
\text { counterparts in order to allow proper information sharing. }\end{array}$ \\
\hline \multicolumn{2}{|l|}{ 7. Resources and Statistics } \\
\hline Resources of Competent Authorities (R.30) & $\begin{array}{l}\text { In relation to the FIU: } \\
\text { - FINTRAC should increase the number of staff dedicated to the analysis of } \\
\text { ML/TF cases; } \\
\text { In relation to law enforcement agencies: } \\
\text { - Canada should increase the resources of the RCMP in relation to ML/TF } \\
\text { investigations; } \\
\text { In relation to the Department of Justice } \\
\text { - Canada should put in place more sophisticated training efforts in the forfeiture } \\
\text { area; } \\
\text { - The authorities in charge of processing MLA requests should be given more } \\
\text { resources; } \\
\text { In relation to prosecution agencies: } \\
\text { - More training should be provided for combating ML and TF; } \\
\text { In relation to supervisors: } \\
\text { - Resources of FINTRAC to carry out its supervision duties should increase. }\end{array}$ \\
\hline
\end{tabular}


- Canada should collect more statistics in relation to ML investigations;

- Canada should collect more statistics in relation to ML sentencing;

- Canada should collect more statistics on confiscation;

- Canada should collect more data on the time requested to respond to extradition and MLA requests;

- OSFI should collect more statistics on the time to respond to a request initiated by its counterparts. 
Canada is strongly committed to the global fight against money laundering and terrorist financing, and has made significant progress to strengthen its anti-money laundering and counter-terrorist financing regime since June 2007.

Additional sets of regulations came into force in June 2008, and more will come into force in December 2008 and early 2009, bringing Canada more into line with the FATF's international AML / CFT standards, and in particular with Recommendation 5. Notably, they will bring new sectors under the regime such as dealers in precious metals and stones, the legal profession, British Columbia notaries, and real estate developers. A new administrative monetary penalties regime is being implemented, which will significantly enhance Canada's sanctions regime.

It is Canada's view that enforcement of these new measures will address the vast majority of the deficiencies identified by the FATF. Additionally, further work is being done to increase the effectiveness of the regime in the following areas: imposing sanctions; enhancing FINTRAC's effectiveness and better assessing money laundering and terrorist financing risks; bolstering money laundering and terrorist financing enforcement and prosecution; and building stronger bridges with private and public sector partners. 